This is the Accepted Version of an article published online by Sage in Critical Sociology on 17 December 2015. Please refer to the published version when citing, available at DOI: $10.1177 / 0896920515616263$

\title{
Marxism and Postcolonial Theory: What's Left of the Debate?
}

(Introduction to Special Issue of Critical Sociology on Marxism and Postcolonial Theory)

\begin{abstract}
Subir Sinha, School of Oriental and African Studies, University of London, UK
\end{abstract} Rashmi Varma, University of Warwick, UK

The very title of this special issue draws attention to a long history of engagement between Marxism and postcolonial theory, virtually from the moment when postcolonial studies appeared as a "field" of study within academic institutions in the Anglo-American world sometime in the 1980s. ${ }^{1}$ This engagement has consisted of collaboration and crossfertilisation as well as considerable antagonism, and various scholars and critics before us have already made their arguments on one side or the other. More recently, Vivek Chibber's book Postcolonial Theory and the Spectre of Capital (2013) appeared on the scene as having unequivocally won the debate for Marxism over postcolonial theory. ${ }^{2}$ We know not only from the vigorous exchanges that took place around the book, as well as the many essays in this volume that cast a critical perspective on both sides, that in fact far from materializing the end of postcolonial theory, the exchanges have been productive in reviving the debate between the two, underlining the need for a remembrance of a longer and older history of contention as well as of its continuing currency, pointing to ways that go beyond the impasse.

Marxists such as Chibber despair that the dominance of postcolonial theory, which they believe to be complicit in the neoliberalisation of diversity and difference in the university, reduces the space for critique and dissent within the academy. Pendakis and Szeman (2014) aver, however, that poststructuralism and its kin - postcolonial theory now "seem(s) as dated as the Soviet factories it once imagined itself to be leaping over into the future" (6), suggesting their obsolescence, rather than dominance. Sandro Mezzadra similarly notes that "under pressure from the current global economic crisis" there has been "the emergence of a new interest in capital and capitalism" within postcolonial theory $(2011: 154)$. There is thus little consensus about whether it is Marxism or postcolonial theory that is dominant in the critical quarters of the academy today. Indeed, concerns about the shrinking space of dissenting and heterodox approaches is an opening to not only continue the debate but to take it in a more fruitful

\footnotetext{
${ }^{1}$ Vasant Kaiwar designates this as "metropolitan postcolonialism", as distinct from the postcolonialism of theory and practice in the formerly colonized worlds where anticolonialism was an important aspect of postcolonial thought (Kaiwar, 2014, p. X). Pranav Jani (2014) calls for the necessity to distinguish postcolonial theory from postcolonial studies, where the latter appears as a vastly eclectic umbrella term encompassing all sorts of approaches, including antithetical ones.

2 In ambition to adjudicate the debate between postcolonial theory and Marxism, although not in content and scope, Chibber's book recalls Aijaz Ahmad's In Theory: Classes, Nations, Literatures (1992).
} 
and politically progressive direction, an invitation to continue conversation rather than to close it down.

Both Marxism and postcolonial theory have a greater degree of heterogeneity of subjects of analysis than is revealed in the most polemical attacks of one position against the other, typically framed as 'culture' versus 'political economy', with considerable overlap in their interest in categories of hegemony, modernity and resistance. ${ }^{3}$ Recent re-engagement between Marxist and postcolonial theory has produced new thinking and writing on world systems, combined and uneven development, world-ecology, the primitive accumulation of capital as an ongoing process and, in literary studies, on the questions of 'world literature' and 'Third-World' aesthetics, opening up fresh ways of thinking the relationship between capitalism, modernity and aesthetic form. This suggests that neither 'Marxism' nor 'postcolonial theory' are stable categories: they are evolving positions, responding both to events and processes in the world, and challenges, internal and external, to their modes of comprehending such events and processes.

The question then is: what is the need now for rehearsing these arguments? What really is left of the debate that deserves to be recuperated for a renewed left politics? What are the new lines along which the debates may now take place? We suggest that although this fraught relationship has been examined in much detail in the work of several scholars over the last few decades, there have been few attempts to provide a critical synthesis that is nevertheless deeply aware of the frequently intractable contradictions between the two. This special issue therefore does not so much as track in any systematic fashion the history of the engagement between Marxism and postcolonial theory from the 1980s to now, as it allows for tracing compatibilities and contradictions between the two approaches where necessary, while building on those engagements to propose new ways of doing social and critical theory today. By posing the formulation as a question mark, in terms of what is remaindered, or remains excessive in relation to the other, we want to draw attention to both a prevailing sense of exhaustion with the debate, and an increasing sense of a renewed urgency for a critical inquiry that would be appropriate for the current global conjuncture. This special issue provides the space first to assess the engagements from the perspective of current shifts and fissures within the study of both postcolonial theory and Marxism; and second to point to new directions that open up when we make such a reassessment from the perspective of today in which new political, economic and social-cultural challenges are appearing.

Both postcolonial theory and Marxism claim to be sensitive to on-going politics, and seek justification in providing critiques of dominant ideology and the current conjuncture. The moment around 2008 and the worldwide economic crisis that characterized it, and in response to which anti-capitalist movements such as the Occupy movement in Europe and the US, the anti-austerity movements in Spain, Portugal and elsewhere in Europe, the Arab Spring in Egypt and Tunisia, among others became widespread and entered popular consciousness, is often marked as a key moment for re-energising the salience of both Marxism and

3 Tim Brennan (2014) in his review of Chibber's book makes the telling point that in many ways the book dramatizes not so much a battle between postcolonial theory and Marxism, but "a more interesting conflict within Marxism itself", between the "humanist and social-scientific interpretations of Marxism". 
postcolonial theory while exposing the limits of each. This conjuncture has been marked by what has been somewhat tongue-in-cheek been named as the "economic turn" in studies of culture and society, involving an "intense, violent, labyrinthine irruption of the economic itself" (Pendakis and Szeman, 2014:7).

Another key component of the conjuncture is the "war on terror" launched in the early 2000s, and that by 2008 was confronting its limits, as the new American century heralded in 2001 seemed to be deflating. This aspect of the conjuncture had already sparked a renewed interest in what David Harvey called the "new imperialism" (2003). Such a renewal of interest in (neo)imperialism happened at the same time as the defeat of party Marxism, the rise and deepening of neoliberalism, the consolidation of 'cultural' identity, the electoral gains made by populist and nationalist governments, and the exhaustion of the social movements of the 1980s-2000. Now confronted with the collapse of the anti-war coalition and the antiimperialist project, the increasing attacks on universalisms such as secularism and feminism, the installation of right-wing sectarian governments in places like India and Turkey, the waning of al-Qaeda and the rise of ISIS, the resurgence of white supremacy and antiimmigration sentiment and policy in Europe and the US, the setbacks to Left and populist movements in Latin America, the emergence of debt/ austerity as dominant forms of economic governance and management, the limitations of narrowly conceived Marxism and postcolonial theory seem to be stretched to the limit.

However, alongside noting the specific lineaments of the current conjuncture, it is important to highlight the asymmetry between Marxism and postcolonial theory that have been set up to debate, an asymmetry that is constitutive of the contours of the arguments on each side. In his recent book Vasant Kaiwar (2014) denotes postcolonial theory as advancing a second order theory in comparison with Marxism which is, as he avers, citing Frederic Jameson, not just a theory of capital but about the "anticipatory expression of a future society". In fact, Kaiwar goes on to state that "postcolonial studies with its poststructuralist, post-modernist imbrications does not have the same value or valences as Marxism; to the extent that postcolonial studies has the ability or ambition to enrich Marxism, it must perforce become an aspect of Marxism..." (xviii). On this view, the "value" of postcolonial theory is entirely derived from the ways in which it can "enrich" Marxism, by becoming an aspect of it. What Kaiwar is suggesting here is an incorporation of postcolonial theory within Marxism such that the debate then becomes an internalised one. But on what terms is still an open question.

While Marxism is a systemic and systematic critique of capital and capitalism, is universalist in its ambition and scope, and reposes faith in causality, totality and revolution, postcolonial theory is a less unified and more slippery entity (Parry 1997). As a framework for analyzing imperialism and colonialism, postcolonial theory, in its dominant formation, has made productive use of notions of contingency, incommensurability, ambivalence and hybridity in order to take down the grand narratives of colonialism and cultural essence (and, less frequently, capitalism). It has offered trenchant critiques of nationalism and Eurocentrism, modernity, class formation, identity, and revolution based primarily on methods and principles drawn from poststructuralist theory. Thus while Marxism provides an overarching analysis of capitalist society, postcolonial theory's analytic approach has been largely premised on deconstructing what it considers to be the overarching power of Western capitalism, imperialism and 'modernity'. Susie Tharu (2007), writing from India and reflecting on her work on feminist and dalit cultural productions, writes of how postcolonial theory 
has been "restrictively attached to an isolated and definitive problematic: colonialism" (643). In a related vein, Mezzadra (2012) has argued that postcolonial theory takes capitalism "for granted", as "neutral background", and thus misses the mark of reading colonialism as part of the historical unfolding of capitalism (155).

This is the key point that Neil Lazarus (2011b) makes in his essay "What Postcolonial Theory Doesn't Say" where he points to a "category error" that is at the heart of postcolonial theory that analyses imperialism in civilizational rather than historical terms such that "the West". For Marxist critics of postcolonial theory, postcolonial studies from the very start have been implicated in the "legitimation of contemporary forms of power" (Dirlik, 1999: 286). In fact for Kaiwar (2014), for whom the 1989 collapse of the Soviet Union was a key moment that precipitated the rise to stardom of postcolonial theory, the 'crisis of capitalism has been a material precondition for the full flowering of postcolonial studies' (xix). In a landscape where all kinds of anti-capitalist and anti-colonial energies were being dissipated, postcolonial theory was seen to be quick to jettison class analysis and condemn national identities as essentialist, thereby strengthening the hand of the increasingly neoliberal academic establishment in the US and UK and its antipathy towards Marxism and its methods.

For Lazarus (2011a), this rejection or antipathy was not evidence of a Cold War anti-Marxism, but constituted an avant garde post-Marxism that was bolstered by the fashionable current of poststructuralism (186). In a discussion hosted by the Publication of the Modern Language Association in 2007 on the future of postcolonial theory, the Africanist literary critic Gaurav Desai (2007) spoke of "the simultaneous rise of a postcolonial orientation that was rather friendly to global flows and formations, that was sceptical of what it saw as the parochialism of older nationalisms, and, without ever publicly admitting it, that jumped on the neoliberal bandwagon, having given up hope of any feasible alternative world order, suggested a sure decline in the field's radical orientation." (641) Lazarus and Rashmi Varma (2008) have described the career of postcolonial studies in a similar vein: "The consolidation of the field in the 1980s and 1990s is at least in part a function of its articulation of a complex intellectual response to the decisive defeat of liberationist and Left movements. On the one hand, as an initiative in tune with the spirit of the age, postcolonial studies breathed the air of the general anti-liberationism then rising to hegemony in the wider society. It has also always characteristically offered, in the scholarship that it has fostered and produced, something approximating a pragmatic adjustment to, if by no means uncomplicatedly a celebration of, the down-turn in the fortunes and influence of insurgent national-liberation movements and anticapitalist ideologies in the early 1970s. On the other hand, as a self- consciously progressive or radical initiative, postcolonial studies was, and has remained, opposed to the dominant forms assumed by anti-liberationist policy and discourse. The intersections of postcolonial studies and multicultural politics provided a domain in which radicalism could be espoused within the constraints of a seemingly undefeatable global order."

Marxism has been seen more broadly as more capacious, possessing a more rigorous method of analysis. Pendakis and Szeman (2014) point to the "omnivorousness of contemporary Marxist thought as a mark of its strength, a desire to contend with diverse positions and to hybridise what it has learned with other strains of thought" (16). Kaiwar (2014) states that "what makes Marxism so rich and able constantly to renew itself is its inexhaustible ability to take on board insights generated within very wide and seemingly unrelated fields of intellectual inquiry and subject them to the 
incomparable critical power of its core concepts and methods of analysis through collective work, polemical exchanges, and so on." (xix) Within Marxist philosophy, as noted by Pendakis and Szeman (2014), the work of Etienne Balibar, Antonio Negri, Alain Badiou, and Slavoj Zizek, among others, reflect "a genuinely dialectical shift within its (Marxism's) own disciplinary and normative space, one that is in some sense being grown from within the limits, exhaustions, and aporias of the tradition itself" (16).

A closer inquiry, however, reveals that not all Marxisms have been open, even if critically, to the insights of postcolonial theory. Zizek (2001) in particular rejects postcolonial theory entirely. Symptomatically, in Zizek's understanding, "postcolonial studies" translates postcolonialism into a multiculturalist problematic - that of the colonized minorities' "right to narrate" against the experience of victimization experienced in interactions with constituted power that repress "otherness". The root of postcolonial exploitation, in this reading, is intolerance toward the Other, and toward the "Stranger in Ourselves". For Zizek the politico-economic struggle is thus displaced by "a pseudo-psychoanalytic drama of the subject unable to confront its inner traumas", resulting in postcolonial theorists' "acceptance of global capitalist coordinates." Zizek's tendency to lump together any sort of 'identity' politics with the 'functional needs of capital', repeated in his "Tragedy and Farce" (2010) First Annual Navayana lecture in New Delhi, comes together with his much-advertised 'defence' of Eurocentrism and universalism, and its lampooning of postcolonial theory. As Menon (2010) and Nigam (2012) point out, Zizek displays a very thin understanding of thought outside Europe, and clings to a hyper-Eurocentrism that would not allow for any postcolonial difference. For all this, however, Almond (2012) slyly identifies postcolonial traces in Zizek's work. It is difficult to see what postcolonial theorists, or even Marxists open to postcolonial theory, can take from Zizek's absolutist position. Badiou, who is also critical of postcolonial theory on the grounds that it provides few openings to understand capitalism and conflict, however, provides grounds for a 'rapprochement' with postcolonial theory with his notion of the 'event'. (Wright 2013)

The lack of usefulness of postcolonial theory in dealing with globalisation and thinking beyond it was also aired in Hardt and Negri's (2000) Empire. Hardt and Negri point to a crisis within postcolonial theory and its inability to explain, let alone critique, globalization, what they define as the emerging system of global sovereignty. "Empire", in their view, "is not a weak echo of modern imperialisms but a fundamentally new form of rule" rendering imperialism no longer an adequate account of power in our times. They find postcolonial theory to be "a very productive tool for rereading history, but it is entirely insufficient for theorizing contemporary global power" (146). They argue that postcolonial theory gives European imperialism a coherence it did not have. While that Empire has not yet materialised, and 'the multitude' seems trumped by the emergence of populist nationalisms worldwide, those critiques are important in terms of thinking about the possibilities of postcolonial theory today. For E. San Juan Jr. (2000), postcolonial theory's obsessive textuality, and its outmoded or inaccurate understanding of the world order under globalisation, makes it no longer relevant in struggles for justice, rights and emancipatory politics generally.

Other writers on Marxism's high table, such as Balibar, do acknowledge the importance of postcolonial theory to rethink their immediate political contexts and impasses. Balibar (2004) directly challenges the 'universalistic' pretensions of Europe, and speaks for the need to uncouple 'Europe' from 'the universal'. In his earlier work, Balibar 
$(1994,2002)$ has argued that 'the universal' is an ambiguous and contested term, articulated in the process of constructing hegemony. This challenges the assumption of stability in the category of 'the universal' which some Marxists invoke in opposition to postcolonial theory's emphasis on difference and particularity. Elsewhere, Balibar has provided resources for a new kind of postcolonial theory to question Europe, its borders, and what it means to be European in an age of migration, refugees, and asylum: 'Europe', he argues, is not only constructed by 'Europeans'. (Balibar 2004) Outside of canonical subaltern studies approach to postcolonial theory in the Indian context, this work resonates with a heterodox postcolonial approach developed by Samaddar (2015) in conversation with Balibar.

If Balibar challenges a static notion of 'universalism', Marxists such as Mezzadra take difference, as elaborated by Chakrabarty's 'history 1 and 2' schema, seriously. While, "the most important contribution of postcolonial studies to the understanding of modernity is usually considered to lie in the multiplication of modernities, in the discovery of alternative paths and experiences of modernization," for Mezzadra, the encounter between 'History 1 ' and 'History 2' is continuously repeated, and Chakrabarty's schema "opens up a theoretical space in which the contestation of modernity, the 'struggle over what it means to be modern, who can claim it, and on what grounds'" can be critically investigated and politically interrogated. This would enable, for Mezzadra, an understanding of different 'histories of labour'. (Mezzadra 2012) Other Marxist postcolonial theorists see Chakrabarty's work as replacing a materialist history of capital that is universal and uneven with an epistemological orientation borrowed from anti-materialist philosophers such as Heidegger (Lazarus and Varma, 2008). In this, Chakrabarty and Mezzadra, seem to neglect Marx's own conception of the history of capitalist production that was of "a complex and differential temporality, in which episodes or eras were discontinuous from each other, and heterogeneous within themselves" (Perry Anderson, 1984:101). More materialistminded postcolonial theory has drawn on Marxist approaches such as Trotsky's theory of combined and uneven development, and Marxisant work in the dependency theory and world systems traditions to make a case for difference within capitalism's history.

Given these quite different responses to postcolonial theory, it becomes difficult to pose some singular 'Marxism' against an equally singular 'postcolonial theory'. Rather, one can ask what forms of Marxism and of postcolonial theory find productive engagement with each other, and in which cases can one declare that the twain shall never meet. This is not surprising for bodies of work that are varied in their thematic and geographical concerns, and vast in sheer volume. Inevitably, Marxists make choices of the theme, period, theory and area focus of some selection of that oeuvre when they position themselves as 'Marxist', and this has consequences for their stand on postcolonial theory. Likewise, postcolonial theorists face and constantly make similar choices between different methods and indeed even ideological positions. How Marxists and postcolonialists regard each other, then, is further a function of what sources they draw on to establish their positions. Does one go with early or late Marx, the mechanistic or the Romantic Marx, or indeed the canonical or the 'Other' Marx? Is one more partial to world systemic derivations from Marx, or to 'political' Marxism? Does one, conversely, follow the postcolonial theory that is inextricable from postmodern and poststructuralist formulations, or one that hitches itself to revolutionary anti-colonial thought? Does one concede that modernity arose in 'Europe' or 'the West', thereby 
underscoring the stability of these terms, or does one see modernity emerging as a single but uneven system? Do we take Quijano's (2000) route that pairs modernity with coloniality, or explore further the co-production of modernity in the colonial encounter as Dussel (1995) suggests? Does one take the 'normal' understanding of capitalism as something that arrives as a result exclusively of the internal history of 'Europe', or as does it arise in the earlier moment of colonization? In the heat of the polemics, these differences within Marxism and postcolonial theory, which exist prior to the differences between them, are dissolved.

One major aspect of the dissension between Marxism and postcolonial theory has been the arraying of the economic realm (seen as the ground of Marxism) against that of the literary and the cultural (seen as the favoured arena of poststructuralist analysis) (Mezzadra 2011, Brennan 2014). In this the priority of the literary-textual, discursive, epistemological-has been seen to signal a political failure. Chibber's book (2013) is a good example of recent work that displays a deep suspicion of "the literary and cultural front" that Brennan (2014) sees as a "blindspot of an otherwise admirable polemic" (74). Instead, Brennan argues that in fact "materialist theories of culture are among the core insights of twentieth-century Marxism" (81). Such a dismissal of the literary and the cultural, as found in Chibber and others, relies on the traditional idea of Marxism as a theoretical apparatus mainly concerned with political economy (approaching the literary and the cultural precisely as "fronts"), which postcolonial theory has simply elided to its detriment. ${ }^{4}$ But there is an important distinction to be made between the somewhat rough understanding of the cultural and the literary sphere that some Marxist work suggests versus the position of critics like Tim Brennan, Neil Larsen, Benita Parry, and Lazarus whose work untangles cultural and literary analysis from the stranglehold of the excesses of poststructuralism and the post-Nietzschean turn in continental theory. Their work variously draws upon the traditions of Marxist literary and cultural criticism of Raymond Williams, Theodor Adorno, Antonio Gramsci, Leon Trotsky, as well as that of Marx himself (Larsen 2001, Schwarz 2001, Parry 2004 and 2009, Lazarus 2011a). But perhaps some Marxists' failure to engage directly with the critical work Marxists working in Literature departments have already produced, has more to do with the fact that the literary and the cultural remain sites that are outside the horizon of their critique. But herein lies a dangerous slippage-in critiquing the cultural turn, there is the possibility of throwing out culture altogether as a site of radical transformation and revolutionary potential.

Here, we think, it would be important to foreground the disciplinary differences in the ways in which the often hostile encounter between postcolonial theory and Marxism is experienced and staged. For critics like Brennan, Larsen, Lazarus, Ahmad and Parry (and Varma as one of the co-editors of this volume), all of whom operate from within the fields of comparative literary studies and cultural studies, the roughshod way in which postcolonial theory threatened to eclipse materialist analysis was felt in an immediate and visceral sense, as it has been in those disciplines that poststructuralist tendencies first struck root and became hegemonic. The advance of post-structuralism was most decisively registered in those fields, eclipsing the materialist anti-colonial tradition of figures like Fanon, Cabral, James. As Brennan (2014) writes: "As the laboratories of theory, literature departments found

${ }^{4}$ This is a fairly common criticism of postcolonial theory, and Chibber is by no means alone in his position (Brennan (2005), Pendakis and Szeman (2014)). 
themselves in the vanguard" (69). And yet, those critics continued to produce work from within the field of postcolonial studies as Marxists, pointing to the fact that the reign of poststructuralism and the resultant disdain for Marxist analysis was never without its dissenters, some of whom continue to be read widely and were seen as important interlocutors, along with Marxist allies like Fredric Jameson and Roberto Schwarz.

Anthropology and History were, it seems, the next in line to "catch up" with the fashionable poststructuralist currents in literary and cultural studies. We will not rehearse here the various accounts already provided by a host of critics of the poststructuralist turn within the Gramscian historiographical project of Subaltern Studies (see Sarkar 1994, Lal 2001, Kaiwar 2014, Chibber 2013). ${ }^{5}$ But the skirmishes between postcolonial theory and Marxism are now staged across a wider range of disciplines. McLennan (2013) notes that it is not surprising that Sociology as a discipline has been a key target of postcolonial criticism for its Eurocentricity, systemthinking, structuralism, empiricism, claims of neutrality and objectivity, as well as abstract universality. He provides examples of a number of key postcolonialist scholars who specifically advocate the eschewing of 'sociological' thinking, not least for the close relation between it and the subjugation of colonised population, and the emergence of ultimately oppressive governmental apparatus. At the level of claims, he sees little to distinguish calls for a postcolonial sociology from anti-sociological positions. He identifies various ways in which sociologists have dealt with the postcolonial challenge. One is Burowoy's call for a 'global sociology from below', in which the postcolonial and 'globalisation' are virtually indistinguishable. Calling for a more radical departure is Mignolo and the de-colonial school, which espouses a de-linking from 'the Eurocentred matrix of knowledge'. Connell advocates bringing Southern scholars into the discipline, and to be open to 'Southern theory' such that a new form of sociology based on plural ways of knowing can emerge. And de Sousa Santos calls for 'intercultural translation' that will help us 're-invent social emancipation'. McLennan is lukewarm to these critiques because they are not that different from critiques from within the discipline, or they end up supporting oppressive positions rather than emancipatory ones, or because they revert to sociological abstraction themselves, such as 'north and south', or 'west versus the rest' etc. Particularly for this issue, it is important that many postcolonial scholars based in places outside of Europe adopt elements of Marxist political economy to understand overarching processes.

A less interrogated discipline within these debates as been that of Development Studies. Development Studies, as Henry Bernstein (2007) notes, emerged as a cross-disciplinary field in the aftermath of post- $2^{\text {nd }}$ World War decolonization, coinciding with the beginnings of the cold war and bi-polarity, and programmes of nation-building. While never the dominant stream, Marxism had considerable presence within the field, existing both in the relatively 'pure' form in agrarian Marxism and 'Warrenism', and also in more heterodox versions such as dependency theory and Maoism. The power of Marxism waned after the 'impasse' debates of the 1980s, in which development studies

\footnotetext{
${ }^{5}$ Brennan (2014) singles out the 1988 publication of Selected Subaltern Studies edited by Ranajit Guha and Gayatri Spivak that made Subaltern Studies a "conduit" for postcolonial theory in the social sciences (71). Lal (2001) made a similar argument earlier when he described the publication of Selected Subaltern Studies as serving the needs of "the burgeoning postcolonial academic industry" (137).
} 
and Marxism were both criticised for their economism, teleology, Eurocentrism and epistemological weaknesses (Corbridge). The conflicts between Marxism and postcolonial theory in this field of study arose because Marxists within development studies, especially economists, were more interested in capitalist development, while others were focused on mass politics. With the rise of Maoism and 'the posts', as well as solidarity with Third Worldist movements and scholarship, anti-imperialism became a politics that no longer was the exclusive or primary preserve of Marxists and working classes, becoming a part of nationalism, peasant and "lumpen-proletarian" politics. Today, leading theorists such as Arturo Escobar use development as a site of production of postcolonial theory, while postcolonial theorists such as Partha Chatterjee are influential in politics and development studies. The return of the Marxist problematic of primitive accumulation in studies of land grabs, agrarian crisis, dispossessions, etc., also provides a point of contact between development studies and postcolonial approaches.

International relations theory is another stage for the tense encounter and engagement between Marxism and postcolonial theory. As a discipline, as Seth (2011) and Blaney and Inayatullah (2016) among others have pointed out, IR is resolutely US- and Eurocentric. It is, simply put, the victor's view of the world. Notable recent Marxian works in IR theory, such as Rosenberg (2000) or Teschke, despite their valuable insights into the origins and development of the international system, are seen to replicate these flaws. Postcolonial IR theorists have pointed to the difficulty conventional IR has with difference, and with weaving them into an understanding of the very constitution of international order. They have argued that colonialism and decolonization must be included as a foundational element of international relations.

What this very brief and selective accounting of the debate so far reveals is that in fact both Marxism and postcolonial theory have been remarkably versatile in terms of responding to new critical challenges. When recent volumes of leading journals in literary studies - the PMLA (Publication of the Modern Language Association) and New Literary History (The State of Postcolonial Studies, Winter 2012, Spring 2012) - devote themselves to the very question about the future of postcolonial theory, based on a sense of the inadequate connection between the field and the state of the world, one is reminded of the persistent auto-criticality that has been a key feature of postcolonial theory in general. ${ }^{6}$ The number of books that have been attempts to critique and recalibrate the field are too many to list here. ${ }^{7}$ Tharu (2007) writes of postcolonial theory as "an exceptionally self-reflexive field. At least half the pages in any reader discuss the filed itself. Postcolonial studies is exercised about its constituency, mode, who it speaks as or for, and so on. In fact, it walks a knife's edge between correct politics and correct theory" (643). And yet for all that, she asks the key question of a theory that always wants to be cutting-edge: what does it cut? In her 2007 intervention on the state of play in postcolonial theory, Susie Tharu, speaking from outside what she calls the "Euro-Am matrix", made an important intervention by asking the question: "what and how is postcolonial cutting?" (p. 644). She writes: "After Marx we are persuaded that

\footnotetext{
${ }^{6}$ See Social Text 31/32 special issue of 1992 on postcolonial studies that drew a widespread response.

${ }^{7}$ A few that we would like to name: The Pre-Occupation of Postcolonial Studies; the Cambridge Companion to Postcolonial Studies; the Loomba et al reader, besides scores of readers and anthologies that have been attempts to survey and review the field.
} 
concepts should be designed as instruments to cut with (tools for change, not for description).... The tough question is, given its location and its concerns, what and how is postcolonial studies cutting?" (643-644). Here Tharu is pointing to precisely the ways in which postcolonial theory's cutting-edge has been dulled by its narrow and limited political horizon.

And yet, we need to be cautious of trends that seem to focus on a reinvention without the necessary rethinking of what it is to do postcolonial theory and Marxism together. In his deliberation on the state of play in postcolonial studies today, Robert Young (2012) presents a classic "add to the mix and stir" move of listing indigenous struggles, political Islam and illegal migrancy as three themes that postcolonial theory had historically neglected and that it now ought to take up as a challenge. Young attributes the crisis of postcolonial theory not to its internal inadequacies and flaws, nor to the externally changed conditions of capitalist crises and new imperial wars, but to the Western academy feeling threatened by the rise of third world countries such as India and China! In fact, Young is emphatic that there is "no need to reinvent theory"; what is important is the need to "locate the hidden rhizomes of colonialism's historical reach, of what remains invisible, unseen, silent or unspoken". With scarcely a mention of capitalism, Young offers "a reconsideration of the role of the postcolonial in the era of the twentyfirst century". But his preoccupation remains with the older postcolonial theory's commitment to the politics of invisibility and of unreadability: "The task of the postcolonial is to make the invisible, in this sense, visible." This is vintage "poco-pomo", the sort of position Zizek's polemic seems to have in mind. What he is suggesting here is not a radical rethinking of the crisis of postcolonial theory, but an enlargement of its scope. ${ }^{8}$

We believe that the essays presented here go beyond the formulae of enlarging and incorporating areas and histories and provide some of the important rethinking so necessary today in order to take the debate further and in new directions. Three essays (Chandra, Nilsen, Sinha) approach the question of 'universalism', a persistent theme in the debate between Marxism and postcolonial theory. Postcolonialists have been sceptical of claims of universalism of capitalism and modernity made by Marxists, and in turn have been accused of denying structurality or mistaking universality for homogeneity. Alf Nilsen's paper here intervenes in the contentions unleashed by Chibber, and identifies both a methodological nationalism and a diffusionist model in which discrete societal units developed autonomous of the rest of the world and then became generalised across the world. Building on the works of Rosenberg and Bhambra, he argues for writing an alternative Marxist historical sociology of capitalism by examining "the emergence and universalization of capitalism as a process that unfolded through and on the basis of a latticework of relations that cut across global space."

\footnotetext{
8 Young's essay can be seen to build on the discussion hosted by the PMLA in 2007 where contributors such as Fernando Coronil, Simon Gikandi, Mamadou Diouf and others related the crisis of postcolonial theory to its narrow horizons that primarily focused on selective histories of colonialism in Asia and Africa, leaving out "other" histories of Latin America and the non-Anglospheric cultural productions in Africa.
} 
Subir Sinha examines three claims of capitalism's 'universalism' made by Marxists in their polemics against postcolonial theorists: the compulsion-driven competition between capitalists, the compulsion of workers to sell their labour for wages in order to subsist, and the emergence of a "worker class" united by their exploitation and precariousness under contemporary capitalism. He argues that the political preconditions for the universalisation of these tendencies do not exist in India, due to incomplete agrarian transitions and the peasantry and working classes created by such incompleteness, the make-up of the Indian bourgeoisie and the state, and the timing of democracy and development. He suggests that India's postcolonial capitalism is different from the early transitions to capitalism; however, it is neither canonical post colonial theory nor canonical Marxism, but a heterodox Marxist political economy that best explains the postcolonial difference in Indian capitalism today.

Also concerned with universalism is Uday Chandra's paper here. Against the highly vituperative tenor of the debate between Marxism and subaltern studies, Chandra, exploring how the positions approach the politics of indigenous people, finds affinities between the positions of Guha and Chibber by showing that they both bear the 'universalism of the resisting subject', as do recent writings on the theme such as Alpa Shah. Even when they claim to provide emic accounts, scholars who claim affiliation to the politics of radical subjects - the working class, peasants or tribals, end up providing etic ones. Chandra suggests a way out of this: to grapple with 'engaged universals', while still retaining thickness and complexity, as well as an interest in comparison.

Lucia Pradella, for her part, while acknowledging the contributions of postcolonial theories to critiques of capitalism, argues that it does not provide a historically and theoretically adequate account of one of its foundational categories: Eurocentrism. She reads Marx's writings on areas outside Europe and North America to recuperate the 'Asiatic Mode of Production' from its status as a pejorative, and instead to show how it informs Marx's writing on a universal category, the 'world working class'. Her work is based on newly available writings of Marx, including material that she has been involved in translating, has provided fresh grounds for rethinking univerasalist notions of globalisation, world working class, world money and so on. She approaches the question of Eurocentrism in general, and in Marx in particular, from these newly translated materials. Her work, too, makes it difficult to sustain the mechanistic Eurocentrism that is often attributed to Marx, and which is often used by critics of postcolonial theory such as Chibber as a stable description of 'the Marxist position'.

Sharad Chari in his essay "Three Moments of Stuart Hall in South Africa" exposes the limits of the debate between Marxism and postcolonial theory via the work of Stuart Hall whom he sets up as the exemplary postcolonial Marxist theorist. For Hall, and for Chari, racism is the prism through which black bodies and spaces experience the depredations of capitalism. He uses the ruined site of a post-industrial Durban, ravaged by environmental pollution and apartheid racism, in order to explore "the possibility of independent and post-nationalist Marxist political thought in Africa today". Chari's essay here argues that the project to create a forward-looking postcolonial Marxism that "imagines futures beyond capitalism, colonialism, and racism in its multiple forms" must build on the emancipatory and radical anti-colonial and anti-capitalist projects of the postcolony. 
Similarly, Rahul Rao finds the polemics of Marxism and postcolonial theory to be limited and indeed even disconcerting as they run against the grain of much progressive scholarship that has been produced in a range of different disciplines. Drawing indirectly upon the work of the queer theorist Eve Kosofsky Sedwick he is instead interested in, the "reparative possibilities immanent within the theoretical formations being criticized". Working from the black Marxism of James and Fanon, Rao is interested in how their theories of oppression and resistance deepen our understanding of intersectionality, as opposed to the often singular axes of analyses deployed by both Marxism and postcolonial theory. His essay is an attempt to take seriously both the material and cultural roots of injustice in our contemporary world.

Paolo Novak's essay suggests that debates are ongoing beyond the main stage on which 'literary' or 'cultural' studies is arrayed against political economy. Perhaps the disciplinary chauvinism, drawing of lines between 'social sciences that matter' and 'humanities that don't' is unhelpful for a sustained and productive engagement between the two approaches. In relatively new fields such as 'development studies', 'gender studies' and 'border studies', inter-disciplinarity is too widespread - and necessary - to be able to entertain these very un-Marxist separation of fields of knowledge. These new and 'peripheral' fields, rather than in the traditional disciplines marked by entrenched positions and established canons, may expose points of intersection between Marxism and postcolonial theories, as both are on unfamiliar ground.

Pranav Jani in his essay turns to the question of refocusing on materialist modes of analysis, having taken into account Marxist critiques of the cultural and linguistic turn that besieged postcolonial theory into a corner. Taking up a key concept from postcolonial theory, especially postcolonial historiography, the fragment as sign of difference, Jani shows how the fragment can be deployed to write better and more accurate histories. Using archival material concerning the role of the "rebel" queen the Rani of Jhansi in the 1857 mutiny in central India, Jani seeks to recoonect the fragment in the archive to the totality of the world outside it, of social relations, as well as the role of mediation. In this, Jani asks the important question: "Do Marxist theories of representation and culture need to side-step the cultural turn? Or have Marxist theories and methods of cultural criticism grown and developed after Subaltern Studies, postcolonial studies, and the like? " Like others in this volume, Jani does not completely repudiate the ambivalent insights of postcolonial theory, but posits a materialist mode of reading that gains from those insights but that remains committed to the task of historical explanation.

The essays in our volume propose that premature declarations of the demise of postcolonial theory and of Marxism are mutually detrimental and limit the explanatory potential of each framework, and chart out some directions in which a productive dialogue between the two might proceed. They do not seek to close debate but to take it forward. While perhaps leaning more to one or the other side in the debate, they do see some productive openings and suggestions in the other. The interdisciplinary and inter-discursive synergy brought to the discussion by essays based in different disciplinary formations is crucial if we are to take this debate in a productive direction.

References: 
Ahmad, A. In Theory: Classes, Nations, Literatures. Verso, 1992.

Almond, I. "Anti Capitalist Objections to the Postcolonial: Some Conciliatory Remarks on Zizek and Context". ariel: a review of international english literature. Volume 43, No. 1: 121, 2012.

Anderson, P. "Modernity and Revolution". New Left Review 1/44, March-April 1984: 96113.

Balibar. E. 1994. "Racism as Universalism", in Masses, Classes, Ideas: Studies on Politics and Philosophy Before and After Marx, New York: Routledge.

Balibar, E. 2002. Politics and the Other Scene. London: Verso.

Balibar, E. 2004: We, the People of Europe? Reflections on Transnational Citizenship (Princeton \& Oxford: Princeton University Press).

Blaney, D and N. Inyatullah (forthcoming 2016), "Difference: Returning International Relations Theory to Heterology." In A. N. Mhurchu and Reiko Shindo eds. Critical Imaginations in International Relations. London: Routledge.

Brennan, T. "Subaltern Stakes". New Left Review 89 Sept-Oct 2014: 67-87.

Brennan, T. "The Economic Image-Function of the Periphery". In Loomba et al Postcolonial Studies and Beyond (101-24).

Chibber, V. Postcolonial Theory and the Spectre of Capital. Verso, 2013.

Desai, G. In Patricia Yeager. Editor's Column: The End of Postcolonial Theory? A Roundtable with Sunil Agnani, Fernando Coronil, Gaurav Desai, Mamdou Diouf, Simon Gikandi, Susie Tharu, and Jennifer Wenzel. PMLA 122.3 2007: 633-651.

Dirlik, A. "Response to the Responses". Interventions: International Journal of Postcolonial Studies 1 2: 286-290.

Dussel, E. The Invention of the Americas: Eclipse of "the Other" and the Myth of Modernity. Continuum, 1995

Hardt, M and Negri A. Empire.

Harvey, D. The New Imperialism. Oxford University Press, 2003.

Jani, P. "Marxism and the Future of Postcolonial Theory". International Socialist Review. Spring 2014. http://isreview.org/issue/92/marxism-and-future-postcolonial-theory-0 (accessed on 30 August 2015)

Kaiwar, V. The Postcolonial Orient. Brill, 2014.

Lal, V. "Subaltern Studies and Its Critics". History and Theory Vol. 40, No. 1 (Feb, 2001): 135-148.

Lazarus, N. The Postcolonial Unconscious. Cambridge University Press, 2011 a. 
Lazarus, N. "What Postcolonial Theory Doesn't Say". Race\&Class. Vol. 53, n. 1 July 2011 b: 3-27.

Lazarus, N. and Varma, R.

Loomba, A., Kaul, S., Bunzl, M., Burton, A., Esty, J. Postcolonial Studies and Beyond. Durham: Duke University Press, 2005.

McLennan, G 2013, 'Postcolonial Critique: the Necessity of Sociology'. Political Power and Social Theory, vol 24., pp. 119-144.

Menon, N. “The Two Zizeks”. Kafila January 7, 2010. http://kafila.org/2010/01/07/thetwo-zizeks/ (accessed on 1 September 2015)

Mezzadra, S. "Bringing capital back in: A Materialist Turn in Postcolonial Studies?" InterAsia Cultural Studies, Volume 12, Number 1, 2011; pp. 154-64.

Mezzadra, S. How Many Histories of Labor? Towards a Theory of Postcolonial Capitalism. Transversal Text, 01, 2012.

http://eipcp.net/transversal/0112/mezzadra/en

Nigam, A. The Zizekian Counter-Revolution. January 3, 2010. Kafila.

http://kafila.org/2010/01/03/the-zizekian-counter-revolution/ (accessed on 1 September 2015)

Parry, B. "Aspects of Peripheral Modernisms". ariel: a review of international English literature. Vol. 40, no. 1, 2009: 27-55.

Parry, B. "The Postcolonial: Conceptual Category or Chimera?" The Yearbook of English Studies Vol. 27, The Politics of Postcolonial Criticism (1997), pp. 3-21.

Pendakis, A. and Szeman, I. "Introduction". Contemporary Marxist Theory: An Anthology. Eds. Pendakis, A., Diamanti, J., Brown, N., Robinson, J. and Szeman, I. (Bloomsbury, 2014)

Quijano, A. "Coloniality of Power, Eurocentrism, and Latin America”. Nepantla: Views from South 1.3, 2000: 533-580.

Rosenberg, J. (1993) The Empire of Civil Society. London: Verso.

San Juan, Jr., E. Beyond Postcolonial Theory. Palgrave Macmillan, 2000.

Samaddar, R. 2015. "The Postcolonial Bind of Greece." Viewpoint Magazine, August 15 2015. https://viewpointmag.com/2015/08/20/the-postcolonial-bind-of-greece/ (accessed September 12015 ).

Sarkar, S. "Orientalism Revisited: Saidian Frameworks in the Writing of Modern Indian History". Oxford Literary Review 16 (1994): 205-224.

Seth, S. (2011), "Postcolonial Theory and the Critique of International Relations." Millennium - Journal of International Studies. vol. 40 no. 1, 167-183. 
Teschke, B. (2003) The myth of 1648: class, geopolitics and the making of modern international relations. London: Verso.

Tharu, S. In Patricia Yeager. Editor's Column: The End of Postcolonial Theory? A Roundtable with Sunil Agnani, Fernando Coronil, Gaurav Desai, Mamdou Diouf, Simon Gikandi, Susie Tharu, and Jennifer Wenzel. PMLA 122.3 2007: 633-651.

Colin Wright, Badiou in Jamaica: The Politics of Conflict. 2013.

Young, R. "Postcolonial Remains". New Literary History. Winter 2012 Volume 43, Number 1: 19-42. Special issue on The State of Postcolonial Studies.

Zizek, S. 2001. "Have Michael Hardt and Antonio Negri rewritten the Communist Manifesto for the twenty-first century?" Rethinking Marxism, volume 13, number 3/4 2001. 